\title{
Early Verb Development in one Croatian-speaking Child ${ }^{1}$
}

\author{
Antigone Katičić \\ Wien \\ antigone.katicic@univie.ac.at
}

\section{Introduction}

This paper shows the early development of the first approximately 50 verbs found in the recorded speech production of one Croatian girl. The aim is to analyse and interpret the child's verb development in terms of the distinction of a pre- and a protomorphological phase before modularised morphology in language acquisition (Dressler \& Karpf 1995). Furthermore, focus will be laid on the emergence of first verb paradigms.

\section{Description of the Croatian Verbs}

\subsection{Grammatical Categories}

The verbal system of the Croatian variety, which is acquired by the child under investigation, can be described with the following verbal categories:

person (1. 2. and 3.), number (singular and plural), mood (synthetic: indicative, imperative, analytic: conditional I and conditional II), aspect (perfective, imperfective), tense (synthetic: present, analytic: perfect, pluperfect, future I and future II ), infinitive and the adjectival past participle agent ${ }^{2}$. Although we have no systematic evidence from the child's input regarding the frequency of the use of verbal categories, one can assume that conditional II, the optative, the patient participle and pluperfect are either not used at all or very rarely. Except for elliptic contexts, e.g. in answers to questions, infinitives and participles hardly appear without finite auxiliary verbs.

Croatian is a pro-drop language. The finite verb agrees with the subject in regard to person and number. Participles (in analytic tense forms) are marked for gender and number.

The child is acquiring an urban variant, usually referred to as Zagreb Kajkavian dialect (ZKD). This dialect differs in many respects from the Štokavian standard variant. ${ }^{3}$ For the purposes of this work it is important to mention that the only form expressing the past is the analytic perfect. Forms of exact future (future II) have the same temporal reference as future I. They are usually used in ZKD to express future tense and not future perfect as in the standard

\footnotetext{
This research was funded by the Austrian Science Fund (FWF P 13371-SPR). It was made possible by the cooperation of two projects at the Department of Linguistics (University of Vienna): „First Language Acquisition of Austrian German" (headed by Chris Schaner-Wolles) and "Pre- and Protomorphology in Language Acquisition" (headed by Wolfgang U. Dressler).

Thanks are due to Dagmar Bittner, Wolfgang U. Dressler, Natalia Gagarina and Marianne Kilani-Schoch for reading and commenting on draft versions of this paper. I would also like to thank Sabine Klampfer and Carmen Aguirre for our long discussions. Christine Czinglar and Katharina Köhler supported me furthermore with helpful ideas. Of course, all errors are mine.

2 Standard (written) Croatian shows furthermore the following categories: imperfect (synthetic), aorist (synthetic), optative, past participle agent and adverbial participles.

3 Works on The Zagreb Kajkavian dialect are among others Magner, Thomas (1966) and Šojat, Antun (1979).
} 
language. In addition, it is typical for ZKD that overt pronouns in contexts which require prodrop in the standard language do not imply emphatic interpretation.

Examples for categories which show up in the child's speech productions in the analysed period are given below exemplified by forms of the verb gledati (to look).

infinitive: gled-a(-)ti

person - number - mood synthetic:

\begin{tabular}{|c|c|c|c|c|}
\hline & \multicolumn{2}{|c|}{ present indicative } & \multicolumn{2}{|c|}{ imperative } \\
\hline & singular & plural & singular & plural \\
\hline 1.pers. & gled-a-m & gled-a-mo & & \\
\hline 2.pers. & gled-a-s & gled-a-te & gled-a-j & gled-a-j-te \\
\hline 3. pers. & gled-a & gled-a-ju & & \\
\hline
\end{tabular}

Table 1. Morphological marking in Croatian synthetic moods ${ }^{4}$.

agent past participle:

\begin{tabular}{llll} 
& masc. & fem. & neut. \\
\cline { 2 - 4 } singular: & gled-a-o & gled-a-la & gled-a-lo \\
plural: & gled-a-li & gled-a-le & gled-a-la
\end{tabular}

aspect: imperfective: pre-gled-av-a-ti (search through)

perfective: pre-gled-a-ti

Prefixation plays an important role in perfective formation, but it hardly has exclusively grammatical function, because it almost always also modifies the lexical meaning of the verb.

tense: synthetic: present gledam, -ǎ́... (see table 1)

analytic: future $\mathrm{I}$ is formed by the clitic forms of the verb htjeti (want) and the infinitive. Future II consists of the perfective forms of biti (be) and the active past participle. Perfect tense is also formed with the latter participle and clitic forms of biti (be).

future I

\begin{tabular}{|l|l|l|l|}
\multicolumn{1}{c|}{} & \multicolumn{2}{c|}{ htjeti clitic (want) } \\
\cline { 2 - 4 } \multicolumn{1}{c|}{} & infinitive & \multicolumn{1}{c|}{ sg. } & \multicolumn{1}{c|}{$\mathrm{pl}}$. \\
\hline 1.pers. & gledat( $i$ ) & $\dot{c} u$ & ćemo \\
\hline 2.pers. & & $\dot{c} e s ́$ & ćete \\
\hline 3.pers. & & $\dot{c} e$ & $\dot{c} e$ \\
\hline
\end{tabular}

Table 2. Future I formation

\begin{tabular}{c|l|l|l|l|l|l|}
\multicolumn{4}{c}{ SINGULAR } & \multicolumn{3}{c|}{ PLURAL } \\
\cline { 2 - 7 } \multicolumn{1}{c|}{$\begin{array}{l}\text { AUX } \\
\text { futureII }\end{array}$} & PARTICIPLE & $\begin{array}{l}\text { AUX } \\
\text { perf. }\end{array}$ & $\begin{array}{l}\text { AUX } \\
\text { future II }\end{array}$ & PARTICIPLE & $\begin{array}{l}\text { AUX } \\
\text { perf. }\end{array}$ \\
\cline { 2 - 7 } 1.pers. & budem & gledao, -la, -lo & sam & budemo & gledali, -le, -la & smo \\
\hline 2.pers. & budeř & & si & budete & & ste \\
\hline 3.pers. & bude & & je & budu & & su \\
\hline
\end{tabular}

Table 3. Future II and perfect formation

\subsection{Inflectional classes}

Being a typical Slavic language Croatian is a fusional-inflecting language type and it is considered to be morphologically rich. The verbal inflectional system consists of many

4 There is also 3. sg. in imperative mood, but it has no distinct inflectional form. It is formed by the particle nek and the indicative present forms.

5 In ZKD auxiliary clitic forms are also used: bum(1.sg.), buš (2.sg.), bu(3.sg.), bumo(1pl), bute(2.pl.), buju (3.pl.). 
distinct morphological classes. ${ }^{6}$ Dressler et al. (1996) establish in their classification of verbal paradigms on the basis of inflectional productivity, 4 major macroclasses with productive microclasses and one recessive class with root inflection and many irregularities. In table 4 only those classes are listed, which show up in the child's production. Classes are referred to by numbers: the first number indicates the respective macroclass, the second number the class, capital letters indicate subclasses and small letters microclasses. Forms given are: infinitive, 1. sg. present indicative, 3. pl. present indicative, imperative, fem. sg. active/past participle. In the following row the plus or minus sign shows whether the respective class is productive or not.

\begin{tabular}{|c|c|c|c|c|c|c|c|}
\hline class & inf. & 1. $\mathrm{sg}$. & 3. pl. & imp. & part. & prod. & engl. \\
\hline $4 / a$ & gled-a-ti & gled-a-m & gled-a-ju & gled $-a-j !$ & gled-a-la & + & look \\
\hline $3 / 1 / a$ & nos $-\boldsymbol{i}-\boldsymbol{t} \boldsymbol{i}$ & $n o s-i-m$ & nos $-e$ & nos-i! & nos-i-la & + & carry \\
\hline $3 / 2 / a$ & vid-je-ti & vid-i-m & vid-e & vid-i! & vid-je-la & - & see \\
\hline $3 / 3 / a$ & $d r \check{z}=a-t i$ & $d r z ̌-i-m$ & $d r z ̌-e$ & $d r z ̌-i !$ & $d r \check{z}-a-l a$ & - & hold \\
\hline $1 / 2 / \mathrm{a}$ & $p i-t i$ & $p i-j-e-m$ & $p i-j-u$ & $p i-j !$ & pi-la & - & drink \\
\hline $2 / 1 / \mathrm{A} / \mathrm{a}$ & ski-nu-ti & $s k i-n-e-m$ & $s k i=n-u$ & ski-n-i! & ski-nu-la & + & take down \\
\hline 2/2/a & pis-a-ti & pišs-e-m & piš $-\boldsymbol{u}$ & piš-i! & pis-a-la & - & write \\
\hline suppletive & biti & (je)sam & (je)su & budi! & bila & - & be \\
\hline isolated & $h t j e-t i$ & $h \circ \dot{c}-u$ & hoć-e & & htje-la & - & want \\
\hline root-cl & $p a-s t i$ & padn-e-m & padn-u & padn-i! & pa-la & - & fall down \\
\hline
\end{tabular}

Table 4. Verb-classes

Among all classes $4 / \mathrm{a}$ is the most frequent, homogenous, transparent and productive microclass, which integrates almost all loan words. Thematic vowels or consonants can be the same in present and infinitive stems as in microclass 4/a and 3/1/a or they can differ as in all other classes. In the 3/1/a microclass pres. 3.sg. and imp. 2.sg. are homophonous, e.g. nosi (carry 3.sg. and imp. 2.sg.).

\section{Data description}

Verb productions treated in this study are taken from a longitudinal corpus of a first-born girl. Antonija, the girl, is growing up in Zagreb and her input is a Croatian urban koine, also called the Zagreb (Kajkavian) dialect (see section 1). The recordings have been transcribed and coded following the norms of CHILDES (MacWhinney 2000). ${ }^{7}$ Figures are calculated on the basis of a preliminary transcribed version of the material. The revised version will probably entail some minor changes.

In terms of age the first 50 verb lemmas appear in the transcribed material between the age of $1 ; 6.15$ and $1 ; 10$. Table 5 shows details of the Antonija corpus:

6 Traditional classifications can, among others, be found in: Babić et al. (1991) and Težak \& Babić (1992). A contrastive presentation of the Croatian inflectional classes in terms of Natural Morphology is presented in Dressler et al. (1996).

7 The material presented here has been collected and transcribed by Draženka Blaži, the mother of the child, in the framework of the project "Psycholinguistic Aspects of the Acquisition of the Croatian Language", Department of Speech and Language Pathology (University of Zagreb). Thanks are due to Melita Kovað̌ević and her collaborators, who supplied me with the material. 


\begin{tabular}{|c|c|c|c|c|}
\hline Session & Age & Duration & $\begin{array}{c}\text { overall } \\
\text { Productions }\end{array}$ & $\begin{array}{c}\text { analysed } \\
\text { utterances }\end{array}$ \\
\hline $\mathrm{AB} 06$ & $1 ; 6.15$ & $10: 58$ & 62 & 48 \\
\hline $\mathrm{AB} 07$ & $1 ; 7.2$ & $12: 32$ & 77 & 74 \\
\hline $\mathrm{AB} 08$ & $1 ; 7.15$ & $19: 03$ & 140 & 107 \\
\hline $\mathrm{AB} 09$ & $1 ; 7.27$ & $12: 45$ & 120 & 91 \\
\hline $\mathrm{AB} 10$ & $1 ; 9.15$ & $20: 55$ & 257 & 205 \\
\hline $\mathrm{AB} 11$ & $1 ; 10$ & $19: 37$ & 155 & 150 \\
\hline
\end{tabular}

Table 5. Data

Note, that there is a period of almost two months where no recordings were made (between 1;7.29 and 1;9.15). The column "overall productions" covers all transcribed units except for babbling, paralinguistic material (e.g. laughing) and unintelligible vocalisations.

The column "analysed utterances" includes all productions but citations (e.g. nursery rhymes and songs), direct imitations and repetitions. ${ }^{9}$ Utterances entailing formulaic or phatic forms, e.g. znaš! (you know!, meaning warning and displeasure), molim (te) (I ask (you), meaning: "please") were also excluded from the analysis.

\section{Predecessors of verbs in predicative function:}

Before and at the beginning of the emergence of the first verbs some predecessors of verbs appear in predicative function. At the age of 1;4.15 there are some approximations to real words of the type bota for baci (throw) and onomatopoetics, e.g. toupa for a doll that fell down. At the age of 1;4.15 one can observe (negated) deictics, which can be interpreted as a part of the predicate: (ne) to ((not) this) and a noun plus a deictic at 1;6.15 teta \# simo (aunt \# here). The latter utterance is expressed while Antonija is asking a woman appearing on TV to come to her. In general the data do not show any obvious recurrent replacement of verbs by neither grammatical nor extragrammatical means.

\section{Emergence of verb forms}

\subsection{Verb production}

Antonija's production of verbs in relation to the overall analysed utterances for each recording session can be seen in table 6 . It shows the occurence of verbs as lemmas ${ }^{10}$ (lexical items), types (different forms of one lemma) ${ }^{11}$ and tokens (occurrences for each specific verb form) in absolute numbers and also in relation to the amount of all analysed utterances. Furthermore, numbers of utterances with verbs and their relation to all analysed utterances are presented. ${ }^{12}$

8 To qualify as an utterance, a production had to include at least one meaningful unit corresponding to a Croatian word in form and meaning.

9 In cases where imitated or repeated utterances were interpreted as appropriate reactions also in regard to adult communication, c.g. answers to questions, they were not excluded from the analysis.

10 Aspectual pairs involving different suffixation, e.g. baciti.perf. - bacati.impf. (throw) are considered as two different lemmas. Paradigmatic opposition of verbs regarding prefixes could not be found in the analysed period. Antonija used a totalof 3 prefixed verbs, but non of these stems showed up with another prefix.

11 Erroneous forms, i.e. non-existing forms in the target language, were counted as types. Such forms are generally rare: in absolute figures there are 4 types of 4 lemmas formed by analogy, class shift and the production of the root form bac (throw) (see section 7).

12 In these figures full analytic forms are counted as two verbs, i.e. they were counted as 2 items for cach group. 


\begin{tabular}{|l|c|c|c|c|c|c|c|c|}
\hline age & lemmas & types & tokens & utt.+verb $^{13}$ & $\%$ lemmas & $\%$ types & $\%$ tokens & $\%$ utt.+verb \\
\hline $1 ; 6.15$ & 7 & 7 & 21 & 21 & $15 \%$ & $15 \%$ & $44 \%$ & $44 \%$ \\
\hline $1 ; 7.2$ & 11 & 12 & 25 & 24 & $15 \%$ & $16 \%$ & $34 \%$ & $32 \%$ \\
\hline $1 ; 7.15$ & 14 & 18 & 28 & 26 & $13 \%$ & $17 \%$ & $26 \%$ & $24 \%$ \\
\hline $1 ; 7.27$ & 14 & 16 & 21 & 18 & $15 \%$ & $18 \%$ & $23 \%$ & $20 \%$ \\
\hline $1 ; 9.15$ & 29 & 39 & 131 & 113 & $14 \%$ & $19 \%$ & $64 \%$ & $55 \%$ \\
\hline $1 ; 10$. & 24 & 30 & 76 & 67 & $16 \%$ & $20 \%$ & $51 \%$ & $44 \%$ \\
\hline
\end{tabular}

Table 6. Lemmas, types and tokens in relation to analysed utterances

Generally, verb production remarkably increases at $1 ; 9.15 .{ }^{14}$ Both utterances with verbs and verbs as tokens represent more than $50 \%$ of the analysed utterances. Lemmas and types are growing at 1;9.15 only in absolute numbers. When relating lemmas and types to the analysed utterances no striking increase shows up.

This distribution can be explained with Antonija's very extensive use of grammatical verbs (copula and auxiliaries) and the occasional omissions of lexical verbs in analytic constructions (see section 4 and 5). By looking more into detail and separating grammatical from lexical verbs one can see, that the increasing token frequency predominantly regards grammatical verbs. Moreover, one can observe an increase of lexical verb tokens in relation to the analysed utterances, but it is by far not as striking. Table 7 shows the corresponding figures of grammatical and lexical verbs in relation to all analysed utterances.

\begin{tabular}{|l|c|c|c|c|c|c|c|c|c|c|c|c|c|}
\cline { 5 - 13 } \multicolumn{1}{c|}{} & \multicolumn{3}{c|}{ lexical verbs } & \multicolumn{3}{c|}{ grammatical verbs } & \multicolumn{3}{c|}{ lexical verbs } & \multicolumn{3}{c|}{ grammatical verbs } \\
\hline age & lem. & typ. & tok. & lem. & typ. & tok. & anal utt. & lem. & typ. & tok. & lem. & typ. & tok. \\
\hline $1 ; 6.15$ & 5 & 5 & 13 & 2 & 2 & 8 & 48 & $10 \%$ & $10 \%$ & $27 \%$ & $4 \%$ & $4 \%$ & $17 \%$ \\
\hline $1 ; 7.2$ & 9 & 9 & 14 & 2 & 3 & 11 & 74 & $12 \%$ & $12 \%$ & $19 \%$ & $3 \%$ & $4 \%$ & $15 \%$ \\
\hline $1 ; 7.15$ & 11 & 14 & 17 & 3 & 4 & 11 & 107 & $10 \%$ & $13 \%$ & $16 \%$ & $3 \%$ & $4 \%$ & $10 \%$ \\
\hline $1 ; 7.27$ & 11 & 13 & 17 & 3 & 3 & 4 & 91 & $12 \%$ & $14 \%$ & $19 \%$ & $3 \%$ & $3 \%$ & $4 \%$ \\
\hline $1 ; 9.15$ & 24 & 31 & 57 & 5 & 8 & 74 & 205 & $12 \%$ & $15 \%$ & $28 \%$ & $2 \%$ & $4 \%$ & $36 \%$ \\
\hline $1 ; 10$ & 19 & 21 & 42 & 5 & 9 & 34 & 150 & $13 \%$ & $14 \%$ & $28 \%$ & $3 \%$ & $6 \%$ & $23 \%$ \\
\hline
\end{tabular}

Table 7. Lexical vs. grammatical verbs

13 Out of all utterances with analytic constructions, 6 utterances contain more that one verb form.

14 In the very first recording the number of utterances with verbs appears to be relatively high (44\%). This could be due to methodological reasons: This early recording still had many utterances entailing babbling and unintelligible vocalisations. These were excluded from the number of analysed utterances, which increased the proportion of verbs. 


\subsection{Verb categories $(1 ; 6.15-1 ; 7.27)$ : premorphology}

The first categories appearing in the corpus are provided in Table 8.

\begin{tabular}{|c|c|c|c|c|c|c|c|c|}
\hline & \multicolumn{2}{|c|}{$1 ; 6.15$} & \multicolumn{2}{|c|}{$1 ; 7.2$} & \multicolumn{2}{|c|}{$1: 7.15$} & \multicolumn{2}{|c|}{$1 ; 7.27$} \\
\hline & lemma & token & lemma & token & lemma & token & lemma & token \\
\hline 1.pres.sg indicative & 1 & 2 & 2 & 2 & 2 & 2 & & \\
\hline 3.pres.sg. indicative ${ }^{15}$ & 4 & 13 & 8 & 16 & 7 & 14 & 9 & 10 \\
\hline 2. sg. imperative & 1 & 5 & 2 & 7 & 3 & 5 & 5 & 9 \\
\hline infinitive & & & & & 1 & 1 & 1 & 1 \\
\hline past part+aux & & & & & 1 & 1 & & \\
\hline ambig. 3Sg/2Imp & 1 & 1 & & & 2 & 3 & & \\
\hline ambig. 1.Pl. Imp./Ind. & & & & & 1 & 1 & 1 & 1 \\
\hline root & & & & & 1 & 1 & & \\
\hline total & 7 & 21 & 12 & 25 & 18 & 28 & 16 & 21 \\
\hline
\end{tabular}

Table 8 . Verb categories $1 ; 6.15-1 ; 7.27$

First verb forms are in most cases present 3.sg. and imperative 2.sg., the former being more represented in lemmas and tokens than the latter. Forms of the $3 \mathrm{sg}$. correspond in lexical verbs to the base form, which is the least marked form ${ }^{16}: p(r) i c a$ (tells), kupa (bathes), $g$ (l)eda (looks), cita (reads). Verb forms in 3.sg. also show up with the affirmative enclitic and the negated copula: (ni)je. The forms baci (throw) and $p(r) i m i$ (grasp) are ambiguous (pres.3.sg./imp.2.sg.). They are also base forms (root+thematic $-i$ ) and belong to the productive microclass 3/1/a (see section 4.4.). Clear instances of imperatives occur with the verbs čekati (wait) and dati (give). The respective forms are čekaj! and daj! Antonija also uses the shortened imperative form $g(l) e$ ! (look) (instead of gledaj!) which is very frequently used in Zagreb. ${ }^{17}$

In present indicative 1. person marking was observed with three verbs: bacim (throw, 1.pers.sg.), nisam (not be (copula), 1.pers.sg.) and neću (not want, 1.pers.sg.). Other categories appear very rarely and mostly in one single lemma.

Plural can be found only with presumably formulaic and rote learnt-expressions in imperative or ambiguously imperative or indicative mood: idemo p(j)evati (let's sing) and bacimo (throw, 1.pl. pres. perfective) or (1.pl.imp.). Moreover one single analytic verb form appears, context bound 3.sg. perf. masc.: pao je (masc.sg. Aux,3.sg. - "he fell down").

When looking at context and meaning of these early verb forms it becomes apparent that $3 . \mathrm{sg}$. forms are used also instead of other categories, e.g. 1.sg. ${ }^{18}$ and imperative.

Examples: Situation: Antonija insists in taking her father's keys from the table.

*MOT: $\quad$ ne macone.

\%eng: $\quad$ no kitty no.

*MOT: $\quad$ to je tatino.

\%eng: this belongs to daddy (lit.: this is paternal).

*ANT: $\quad$ (h)oće.

\%eng: $\quad$ want (3.sg.).

15 The enclitic and emphatic form of the copula have been counted as two different lemmas.

16 Also according to analyses, where - $a$ - is not considered being a thematic vowel but a part of the person/ number suffix (Babić et al. 1991 and Težak \& Babić 1992), the 3.sg. represents the least marked form.

17 Besides gle there is also the reduced cek instead of čekaj (wait!) used in ZKD very often reduplicated (čekcek!).

18 Sometimes it is hard to decide whether the child refers to herself in the 3.sg. as many children do in this age or whether she skips the I.sg. agreement marker. But there are also instances, where the pronominal subject is overt while the realised verb does not agree in number and person, e.g. ja p(r)ima (I grasp,3sg.) (see section 5). 
Situation: Antonija brings a picture-book to her mother and asks her to read.

*ANT: $\quad$ cita! $!^{19}$

\%eng: $\quad$ read (3.sg.)!

Generally, Antonija's verb production's in sessions 1;6.15-1;7.27 indicate, that she is in the premorphological phase, devoid of any specific morphological activity. In this period verb forms appear to be non-analysed and rote learnt (see MacWhinney 1978 and Dressler \& Karpf 1995). Lemmas show up in just one single form. Exceptions in this respect are the verb baciti and the negated copula (auxiliary) ne biti (see section 6). Suffixes marking person and number in the target language are often skipped in lexical verbs, hence replaced by 3.sg. forms. Infinitives and participles are very rare and when used they seem to be strictly contextbound.

\subsection{Verb categories $(1 ; 9.15 \& 1 ; 10)$ : protomorphology}

Table 9 shows the verbal categories produced by the child after almost two months. The numbers in the cells are to be interpreted as lemmas / tokens. Infinitives and participles which have been produced with finite verbs (e.g. in analytic tense forms or with modal verbs) are referred to underneath their respective category.

\begin{tabular}{|c|c|c|c|c|c|c|c|c|c|}
\hline & 1. sg. & 2. sg. & 3. sg. & 1. pl & 3. pl. & fem. sg. & masc. sg. & plural & inf. \\
\hline pres. ind. & $9 / 31$ & $6 / 8$ & $7 / 69^{20}$ & & & & & & \\
\hline +inf. & $0 / 3$ & & & & & & & & $2 / 3$ \\
\hline imp. & & $7 / 18$ & & & $1 / 1$ & & & & \\
\hline+ inf. & & & & $1 / 2$ & & & & & $1 / 2$ \\
\hline fut.I: aux & $2 / 21$ & & & & & & & & \\
\hline aux+inf. & $0 / 9$ & $1 / 1$ & & & & & & & $6 / 10$ \\
\hline fut.II: aux & $2 / 2$ & & $1 / 2$ & & & & & & \\
\hline aux+part. & & & $0 / 2$ & & & $1 / 1$ & $1 / 1$ & & \\
\hline perf.:aux & $3 / 6$ & & $1 / 1$ & & & & & & \\
\hline aux+part. & $0 / 5$ & $1 / 1$ & & & & $6 / 6$ & & & \\
\hline infinitive & & & & & & & & & $1 / 1$ \\
\hline part. & & & & & & & & $1 / 1$ & \\
\hline total & $16 / 77$ & $15 / 28$ & $9 / 74$ & $1 / 2$ & $1 / 1$ & $7 / 7$ & $1 / 1$ & $1 / 1$ & $10 / 16$ \\
\hline
\end{tabular}

Table 9. Verb categories: $1 ; 9.15 \& 1 ; 10$

After the long recording interval, Antonija produces more and new verb (sub)categories. In addition to 3 . person, also the other persons, especially 1 . singular, are used productively in singular indicative mood. Lexical verbs are marked with the respective suffixes $(-m,-\check{s})$, e.g. zezam (tease.1.sg.), znam (know.1.sg.), nemam (not have.1.sg.) imaš (have.2.sg.), p(r)ičaš (tell.2.sg.).

First analogical errors appear: hoćem ${ }^{21}$ (want,1.sg.). The verb htjeti (want) has an irregular suffix (hoć-u) as 1. sg.-suffix in the target language. The form used by the child shows that she has identified the "theme plus $-m$ " suffix as 1 . sg. marking. ${ }^{22}$

19 Note that in the same session Antonija produces the full target form, (base plus final $-j$ ) of a phonological similar verb, which belongs to the same class: čekaj!

20 Among the $693 . \mathrm{sg}$. tokens there are 55 instances of the copula.

21 Although hocem is also used in ZKD, Antonijas mother confirmed my impression, that this form was not used in the family and by the social surrounding the child was confronted with.

22 For similar findings in another Croatian child see Andel et al. (in press). 
All analytic forms of infinitives (fut. I) and participles (fut. II and perf.) are used productively: ja ću bombicu popapati (I AUX.fut.I candy.dim.akk. eat up.inf. - "I will eat up the candy"), bude jodija [: rodila] \# mama (AUX.fut.II give birth.part.fem.sg. \# mummy - "mummy will give birth") and ja <san dobija> [: sam dobila] c(v)ijeće. (I AUX.perf. get.part.fem.sg. flowers - "I got flowers"). Except for two instances, participles and infinitives are almost exclusively used in analytic verb forms. Gender marking on participles is in most cases feminine, presumably because the girl refers usually to herself. Though when referring to her father, in one instance, she used the masculine participle.

Plural forms are still rare. They appear with the same lemmas as in the earlier sessions and under contextually bound or dubious circumstances: idemo p(j)evati! (let's sing!).

Antonija's (morpho)syntactic development shows up not only in the use of analytic forms. Generally she seems to have a preference for grammatical verbs (see section 5). $55(27 \%)$ of the 207 analysed tokens are copulas 3.sg.. Moreover, when analytic forms are elliptic, the lexical part tends to be omitted. This holds especially for future I forms, such as in:

Situation: Antonijas mother wants to have a certain pencil.

*MOT: $\quad$ hoćeš mi dati?

\%eng: $\quad$ AUX/MOD.2.sg. to me give?

*ANT: $\quad$ ne.

\%eng: no.

*ANT: $\quad$ jaću tebi drugu.

\%eng: $\quad$ I AUX.1.sg. you,dat. one/the other $»$ I will to you another «

In sum, Antonija shows new verb categories and erroneously regularised verb forms. Moreover her category substitutions and agreement errors almost totally disappear. Due to these observations one can assume that at the age of 1;9.15 Antonija is already in the protomorphological phase.

\subsection{Verb Classes}

The following table 10 provides an overview of the distribution of inflectional classes in Antonijas production. The numbers in the cells correspond to lemmas/types/tokens.

\begin{tabular}{|c|c|c|c|c|c|c|c|c|}
\hline Class & example & $1 ; 6.15$ & $1 ; 7.2$ & $1,7.15$ & $1 ; 7.27$ & $1 ; 9.15$ & $1 ; 10$ & total \\
\hline $4 / \mathrm{a}$ & gledati, -am & $1 / 1 / 5$ & $7 / 7 / 12$ & $5 / 5 / 7$ & $5 / 6 / 9$ & $14 / 16 / 31$ & $8 / 8 / 8$ & $40 / 43 / 72$ \\
\hline $3 / 1 / \mathrm{a}$ & nositi, -im & $1 / 1 / 1$ & $1 / 1 / 1$ & $2 / 5 / 6$ & $3 / 3 / 3$ & $4 / 4 / 4$ & $4 / 4 / 5$ & $15 / 18 / 20$ \\
\hline $3 / 2 / \mathrm{a}$ & vidjeti, - im & & & & $1 / 1 / 1$ & & & $1 / 1 / 1$ \\
\hline $3 / 3 / \mathrm{a}$ & držati, -im & & & & & $1 / 1 / 5$ & & $1 / 1 / 5$ \\
\hline $1 / 2 / \mathrm{a}$ & piti,-jem & & & $1 / 1 / 1$ & & $1 / 1 / 1$ & & $2 / 2 / 2$ \\
\hline $2 / 1 / \mathrm{A} / \mathrm{a}$ & skinuti, -nem & & & & & & $2 / 2 / 2(1 *)$ & $2 / 2 / 2$ \\
\hline $2 / 2 / \mathrm{a}$ & pisati, -šem & $1 / 1 / 1 *$ & & $1 / 1 / 1$ & & $1 / 1 / 1$ & $1 / 1 / 1$ & $4 / 4 / 4$ \\
\hline suppl. & biti, (je)sam & $2 / 2 / 8$ & $2 / 3 / 11$ & $4 / 5 / 12$ & $4 / 5 / 6$ & $5 / 9 / 53$ & $5 / 11 / 45$ & $22 / 35 / 135$ \\
\hline isolat. & htjeti, hoću & $2 / 2 / 6$ & $1 / 1 / 1$ & & $1 / 1 / 2$ & $3 / 7 / 36$ & $4 / 4 / 15$ & $11 / 15 / 60$ \\
\hline root-cl. & pasti, padnem & & & $1 / 1 / 1$ & & & & $1 / 1 / 1$ \\
\hline
\end{tabular}

Table 10. Inflectional classes in Antonijas verbs

In lemmas, types and tokens throughout the analysed sessions there is a dominance of two types of classes: on the one hand suppletive and isolated paradigms, and on the other 4/a and $3 / 1 / \mathrm{a}$, the two most homogenous and transparent classes. The preference for non-homogenous and morphotactic opaque suppletive and irregular verbs are connected with the extensive use of grammatical verbs, which have high token frequency also in the target language (copula 
and modal or auxiliary (ne) htjeti ((not) want): (64\% tokens / 41\% types / 33\% lemmas). On the other hand Antonija's lexical verbs throughout the sessions show a preference for transparent patterns. The most productive, homogenous and frequent ${ }^{23}$ class in the target language is also the by far best represented class in the child's lexical-verb productions. $24 \%$ of all tokens $35 \%$ of all types and $40 \%$ of lemmas can be attributed to the class 4/a. The less productive, but also very transparent and frequent class in Croatian, 3/1/a, is continuously used by the child, though to a smaller extent ( $7 \%$ tokens $/ 15 \%$ types $/ 15 \%$ lemmas). At the beginning of protomorphology, when the child begins to use also infinitive and participles, these categories show up with verbs of the 4/a and 3/1/a class, which have no (present infinitive) stem alternation, e.g. pjevala (sing. part.fem.sg.) and pjeva (3.sg.pres.) (see section 6.).

Considering the few verb forms which belong to less frequent and more opaque classes, it appears that they show up in those forms which could be forms of the 4/a and 3/1/a class: inf. dužati [: držati] (hold.2.sg.imp.), vidi (see.part.fem.sg.), plakaja [: plakala] (cry.part.fem.sg.) etc. On the basis of these forms alone, without any opposition to other forms which involve different bases (e.g. $d r z ̌ i$ (hold.3.sg.pres.) and $d r z ̌ a t i$ (infinitive)), there is no evidence that the child differentiates those classes from the homogenous ones.

Finally, class shifts indicated with an asterisk in table 10 also show a preference for these transparent patterns (see section 7).

\section{Syntactic usage}

First verb forms appear as one-element utterances. This holds for the sessions $1 ; 6.15$ and 1;7.2. At 1;7.15 and 1;7.27 Antonija has both one- and two-element utterances. Verbs with predominantly grammatical meaning, i.e. copula and auxiliary verbs are among the earliest forms. Out of 95 verb tokens $(1 ; 6.15-1 ; 7.27), 34(36 \%)$ are grammatical verbs. ${ }^{24}$

It has already been shown in section 4.2., that the context in which early verb forms appear (1;6.15-1;7.27), indicates that Antonija does not use grammatical categories according to the target language. This holds especially for the 3. sg. pres. (see section 7 ). ${ }^{25}$

In cases with an overt pronoun and a non-agreeing verb also the syntactic context shows that 3. sg. replaces other categories (in this case 1. sg.) :

$1 ; 7.15$ ja prima (I grasp.3sg.)

$1 ; 7.27$ vidi ja (see.3.sg. I)

At 1;9.15 Antonija's productions show that a striking syntactic development has taken place: Utterances with more than three elements appear and finite verbs show person and number agreement with overt subject-pronouns. The use of grammatical verbs increases dramatically: there are $108(52 \%)$ grammatical verb tokens out of total 207 verb tokens in the sessions recorded in $1 ; 9 ; 15 \& 1.10$. Moreover adverbs, direct and indirect object pronouns and analytic tense forms emerge in these sessions: neću tebi dati (neg.AUX/want.1.sg. you.dat. give - »I will not give to you «), i ja ću ovo dužati [: držati] (and I AUX.1sg. this.acc. hold - »and I will hold this «). The child also starts using constructions consisting of modal verbs and infinitives: (h)oću (o)vako dužati [: držati] (»I want hold like this«). Out of 180 analysed utterances with verbs, $23(13 \%)$ contain verbal constructions with two overt verbs, i.e. periphrastic tenses and

23 Unfortunately, there is no input analysis available yet. It would be interesting to control the factor of classfrequency in the target language.

24 More details are given in Katičić (1997).

25 For similar findings with another Croatian girl see Anđel, et al. (in press). 
infinitives with finite modal verbs. Finally, at 1;10 Antonija shows the first co-ordinate clause: nisam pevaja [: pjevala] nego sam pakaja [: plakala] (»I did not sing but I cryed «).

\section{Emergence of mini-paradigms}

This section focusses on the child's paradigmatic form-meaning distinction on the basis of lemmas $^{26}$. Kilani-Schoch \& Dressler (2000) propose five criteria for establishing the onset of a paradigm ${ }^{27}$ : i.e. spontaneous production (not imitative, not formulaic), articulatory accuracy, use in contrasting contexts and recurrence. Instances which fulfill these criteria are termed as "mini-paradigms", since they are already "true" but not complete paradigms. The emergence of mini-paradigms is taken to be an indicator for the fact that the child has identified morphology. In this sense the question arises, whether the emergence of mini-paradigms coincides with other factors, which indicate or which accompany the child's developmental changes.

\subsection{Qualitative analysis}

Following the proposed criteria we find the following true mini-paradigms (three-types of the same lemma) and furthermore also two-member mini-paradigms as candidates for true miniparadigms in the Croatian data:

Table 11 and table 12 provide information about the child's paradigm formation activity. The first shows the emergence of true mini-paradigms, the latter two-member mini-paradigms.

In order to allow comparability of different languages and different corpora, mini-paradigms were counted per month of life. Therefore three-member mini-paradigms, which appear in a short interval but not in the same month of life were not counted as true mini-paradigms. Though, for a qualitative description, additional forms of paradigm candidates were also listed in table 12 below.

\begin{tabular}{|c|c|c|c|c|c|}
\hline Age & Lemma & Forms & Category & $\begin{array}{c}\text { Class, inf., pres. } \\
\text { marking }\end{array}$ & English \\
\hline \multirow[t]{3}{*}{$1 ; 7$} & baciti(?) & baci & 3. sg.pres./2.sg.imp. & 3/1/a, $-i t i,-i m$ & throw \\
\hline & & bacim & 1. sg. pres. & & \\
\hline & & bacimo & 1. pl. pres//imp. & & \\
\hline \multirow[t]{3}{*}{$1 ; 9$} & biti & sam & 1. sg. pres. & suppletive & want \\
\hline & & si & 2. sg.pres. & (clitic) & \\
\hline & & je & 3. sg. pres. & & \\
\hline \multirow[t]{3}{*}{$1 ; 10$} & $i c ́ i$ & idem & 1. sg.pres. & suppletive & go \\
\hline & & ideš & 2. sg.pres. & & \\
\hline & & ide & 3. sg. pres. & & \\
\hline
\end{tabular}

Table 11. True mini-paradigms

For the definition of lemma see section 4.1. and footnote 10.

A paradigm is defined as all inflectional forms of the same lemma. 


\begin{tabular}{|c|c|c|c|c|c|}
\hline Age & Lemma & Forms & Category & $\begin{array}{c}\text { Class, inf., pres. } \\
\text { marking }\end{array}$ & English \\
\hline $1 ; 9$ & dati, dam & $d a j$ & 2. sg. imp. & 4/a, -ati, -am & give \\
\hline $1 ; 9$ & & dati & infinitive & & \\
\hline $1 ; 9$ & gledati, -am & g(l)eda & 3. sg. pres. & 4/a, -ati, -am & look \\
\hline $1 ; 9$ & & g(l)edali ${ }^{28}$ & part.(masc.) pl. & & \\
\hline \multirow[t]{2}{*}{$1 ; 9$} & $i c ́ i$ & idem & 1. sg.pres. & suppletive & go \\
\hline & & ide & 3. sg. pres. & & \\
\hline $1 ; 10$ & & $g(l) e$ & 2. sg. imp. (ZKD) & irregular & \\
\hline $1 ; 9$ & pjevati $^{29}$ & p(j)evati & infinitive & 4/a, -ati, -am & sing \\
\hline $1 ; 10$ & & $p(j) e v a l a^{30}$ & part. fem. sg. & & \\
\hline $1 ; 9$ & htjeti & (h)oć & 1. sg. pres. & isloated & want \\
\hline $1 ; 9$ & & (h)oćeš & 2. sg. pres. & & \\
\hline \multirow[t]{2}{*}{$1 ; 10$} & biti & sam & 1. sg. pres. & suppletive & be \\
\hline & & je & 3. sg. pres. & (clitic) & \\
\hline \multirow[t]{2}{*}{$1 ; 10$} & ne biti & nisam & 1. sg.pres. & suppletive & not be \\
\hline & & nije & 3. sg. pres. & & \\
\hline
\end{tabular}

Table 12. Two-member mini-paradigms

Already in the premorphological period Antonija shows the first three-form-opposition of the same lemma. It is very dubious, whether this instance should be identified as a "true" miniparadigm in Kilani-Schoch's and Dressler's (2000) sense. The contrastive contextual appropriateness of the respective forms of baciti (throw) is questionable. The child uttered them in very short intervals in a quite playful way while playing with a ball, producing also the root bac. Apart from this there was no other instance of morphological opposition in any other lemma in this early period.

In those sessions $(1 ; 9.15 \& 1 ; 10)$ where Antonija can be considered as having already entered the protomorphological stage, the various true mini-paradigms and two-member miniparadigms show up.

The first clear mini-paradigms are suppletive verbs. In the case of the clitic verb biti (be) the early appearance is in accordance with Antonija's extensive use of copula and auxiliaries. On the one hand, forms of biti show a very high degree of opacity and irregularity throughout the whole paradigm. On the other hand, all three forms of the verb ici (go) show a transparent pattern.

The categories in which first mini-paradigms appear are predominantly indicative singular forms. Looking also at two-member pairs one sees the majority of forms being either 1 . or 3 . person. To a smaller extent, 2.sg. imperatives and infinitives are involved in paradigm formation. Categories involving both stems (infinitive and present) appear first with verbs of the most homogenous class (4/a) (see section 4.4.).

\subsection{Quantitative analysis}

Since the number of mini-paradigms attested in one corpus depends on sample size, we propose two sample-size independent values for investigating the development of the paradigm-formation capacity in a child. The first value ( $\mathrm{P}(\mathrm{utt})$ ) is calculated by dividing the number of mini-paradigms by the number of analysed utterances per month. The second value $(\mathrm{P}(\mathrm{lem}))$ sets the number of mini-paradigms in relation to the number of verb lemmas used in a given month of age. The paradigm values $\mathrm{P}(\mathrm{utt})$ and $\mathrm{P}(\mathrm{lem})$ are supposed to provide an

28 Uttered as g(l)edaji.

29 Antonija uttered at $1 ; 7.27 p(j)$ eva (3. sg. pres.). It can be assumed that she is still able to produce this form.

30 Uttered as p(j)evaja. 
objective base for comparison of mini-paradigms across different corpora and languages (see also Klampfer and Aguirre in this volume).

\begin{tabular}{|c|c|c|c|c|}
\hline Age & \multirow{2}{*}{$\begin{array}{c}\text { 2-member } \\
\text { mini-parad. }\end{array}$} & \multirow{2}{*}{$\begin{array}{c}\text { true-MP } \\
\text { mini-parad. }\end{array}$} & \multicolumn{2}{|c|}{ paradigm values } \\
\cline { 4 - 5 } & 0 & 0 & $0 / 48=0 \%$ & $\mathrm{P}(\mathrm{lem})$ \\
\hline $1 ; 6$ & 0 & 1 & $1 / 272=0,4 \%$ & $0 / 7=0 \%$ \\
\hline $1 ; 7$ & 4 & 1 & $4 / 205=1,9 \%$ & $4 / 29=13,8 \%$ \\
\hline $1 ; 9$ & 2 & 1 & $3 / 150=2 \%$ & $3 / 24=12,5 \%$ \\
\hline $1 ; 10$ & & 1 &
\end{tabular}

Table 13. Paradigm values

Both paradigm values, $\mathrm{P}(\mathrm{utt})$ and $\mathrm{P}(\mathrm{lem})$, increase remarkably at $1 ; 9$. $\mathrm{P}(\mathrm{utt})$ shows that the proportion of mini-paradigms grows independently of sample size. $\mathrm{P}(\mathrm{lem})$ shows the relation to the lexical production of verbs. It provides a child and language specific value. The proportional increase of mini-paradigms confirms other findings which indicate that Antonija at this age becomes morphologically active, i.e. that she is in the phase of protomorphology.

\section{Morphological substitutions}

\subsection{Category substitution:}

Category-substitution is the most frequent type of substitution that can be observed in Antonijas data. The direction of substitution is almost exclusively towards indicative pres. 3.sg. This type of substitution (omission of markers) is typical for the premorphological period $(1 ; 6.15-1 ; 7.27)$.

Examples are given below: 1;6.15 (h)oću (1.sg.pres.)> (h)oć $e^{31}$ (want.3.sg.pres.)

1;7.2 gledam (?) (1.sg.pres) $>$ g(l)eda (look.3.sg.pres.)

1;7 čitaj! (2.sg.imp.) > čita! (read.3.sg.pres.)

1;7.27 vidim (ja) > vidi ja (see.3.sg.pres. I)

\subsection{Analogy and class shift}

After omitting the pres. 1.sg.-suffix $(1 ; 6.15-1 ; 7.27)$ in the verb htjeti (want) Antonija starts marking 1.sg.pres. by analogy to all other verbs with the suffix $-(e) m$. From now on she produces the form hocem (see section 4.3.).

Class shifts are rare in Antonija's data. In total two instances were found (see section 4.4.).

Both cases show transparent forms substituting opaque ones.

1;6.15: classes: 2/2/a > 4/a pišse $>$ pisa (write.3sg.)

1;10: classes: 2/1/A/a >3/1/a kucnuti $>$ kuciti (knock.inf)

\subsection{Lexical substitutions}

Especially in the period $(1 ; 9.15$ and $1 ; 10)$, when Antonija starts using periphrastic forms, the infinitive of lexical verbs is occasionally substituted by other elements, e.g. deictics:

1;10 ja cu (o)vako (I will that way.) The context of the latter utterance is the following: in displeasing her mother Antonija announces, that she intends to draw on the table.

31 Phonologically similar contexts indicate that the child at that time was able to produce final $-m$. 


\section{Conclusion}

According to the observations mentioned in the previous sections one can assume that at 1;9.15 Antonija is already in the protomorphological phase. Analogy errors (hoć $>$ *hoćem), the end of agreement errors, syntactic development, the use of more and different verbal categories and finally, the emergence of mini-paradigms indicate that the child has become morphologically active. ${ }^{32}$ Presumably because of the long recording interval $(1 ; 7.27-1 ; 9.15)$ no transition phase could be observed.

Regarding quantitative distribution, the emergence of mini-paradigms coincides with an increase in verb production and a syntactic spurt, but according to percentages, there is no verb spurt accompanying morphological development.

The earliest category to appear is 3. sg. pres. indicative and 2. sg. imperative. Both categories correspond to the least marked base form (root and thematic vowel) of the paradigm in lexical verbs. But, for the for 2. sg. imp., this holds only for one verb class. In indicative mood verbs in 1. pers. singular are more marked forms. They also emerge early, but are very rare. ${ }^{33}$ The preference for the 3.sg. pres. respectively the base form shows up also in category substitutions. The latter are characteristic for Antonija's early sessions, where she is assumed to be in the premorphological phase.

Clear oppositions in person (synthetic) and tense (for all non present tenses analytic) marking appear for the first time in the same recording-session (1;9.15). Because of the lack of data for 1,5 months it is not possible to definitely find out whether both categories appear at the same time or whether one category appears before the other. The relatively early emergence of analytic tense forms could be due to the fact that the target language has synthetic forms only in present tense. The category of person is marked distinctively by the child before number. Besides semantic markedness this could be due to the fact that both categories are distinctively marked in the target language.

As regards classes, Antonija shows on the one hand many suppletive and irregular verbs. Because of their grammatical function, they are also high-token-frequency verbs in the target language. Nevertheless, Antonija's strong tendency of using grammatical verbs is atypical for child language in general. Possible reasons for this will have to be looked for in future work including also syntactic analysis. Moreover it will be of interest, whether this behaviour is child- or also language-specific.

With lexical verbs on the other hand, she shows a preference for homogeneity and transparency. The most productive, frequent and thus transparent classes in the target language (4/a and 3/1/a) are also the most frequent classes in Antonija's lexical-verb productions. Moreover, class shifts, the early emergence of forms involving both (present and infinitive) stems and their absence with verbs belonging to other, more opaque classes show the child's preference for transparency and homogeneity.

32. Additional evidence from Antonijas development in the nominal system will be provided in future analyses.

33 Anđel et al. (in press) found a similar order of emergence in their contrastive study of the acquistion of Croatian, French and Austrian German. 


\section{References}

Anđel, Maja \& Sabine Klampfer \& Marianne Kilani-Schoch \& Wolfgang U. Dressler \& Melita Kovačević (in press): Acquisition of verbs in Croatian, French and Austrian German - an outline of a comparative analysis. Suvremena Linguistinka.

Babić, S. \& Dalibor Brozović \& Milan Moguš \& Slavko Pavešić \& Ivo Škarić \& Stjepko Težak (1991): Povjesni pregeld, glasovi i oblici hrvatskoga književnog jezika. Zagreb: HAZU i Globus.

Dressler, Wolfgang U. \& Annemarie Karpf (1995): The Theoretical Relevance of Pre- and Protomorphology in Language Acquisition. Yearbook of Morphology 1994. 99-122.

Dressler, Wolfgang U. \& K. Dziubalska-Kołaczyk \& A. Katičić (1996): A Contrastive Analysis of Verbal Inflection Classes in Polish and Croatian. Suvremena Lingvistika.127-138.

Katičić, Antigone (1997): Zum Erstspracherwerb des Kroatischen: morphologische und syntaktische Aspekte beim Erwerb des Verbalsystems, MA-thesis, University of Vienna.

Kilani-Schoch, Marianne \& Wolfgang U. Dressler (2000): The emergence of two French corpora as an illustration of general problems of pre- and protomorphology. Poster at the $9^{\text {th }}$ international Morphology Meeting, February 2000. to appear in a volume edited by M. Voeikova \& W.U. Dressler

MacWhinney, Brian (1978): The Acquisition of Morphophonology. Chicago: Univ. of Chicago.

MacWhinney, Brian (2000): The CHILDES project: tools for alalyzing talk. Mahwah, NJ: Lawrence Erlbaum Associates.

Magner, Thomas F. (1966): A Zagreb Kajkavian Dialect. in: The Pennsylvania State University Studies No. 18., Pennsylvania State University.

Šojat, Antun (1979): O zagrebačkom kajkavskom govoru. Rasprave Zavoda za jezik Institutua za filologiju i folkloristiku 4-5. 119-123.

Težak, S. \& S. Babić (1992): Gramatika hrvatskoga jezika. Zagreb: Školska knjiga. 